\title{
NEW STUDIES IN THE AMMONOOSUC DISTRICT OF NEW HAMPSHIRE
}

BY C. H. HITCHCOCK

(Presented before the Society December 30, 1903)

CONTENTS

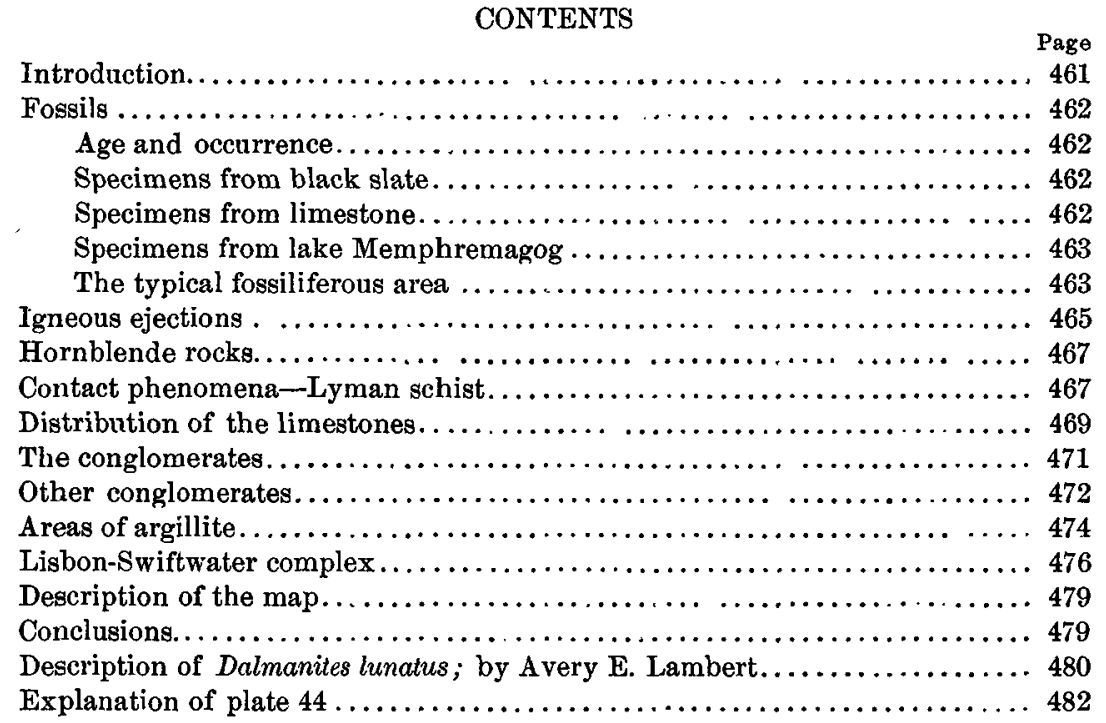

INTRODUCTION

In 1877 the writer published in the second volume of the Geology of New Hampshire a general description of the rocks of the Ammonoosuc district, the region extending from Woodsville to Lancaster, where the Connecticut river bends conspicuously to the west and has apparently annexed a part of Vermont to New Hampshire. The Connecticut has cut across a mountainous range in what is known as the Fifteen Miles falls, causing the drainage of the upper part of the state to unite with that of the Passumpsic river. On some other occasion $I$ hope to revive an old theory, advocating the former drainage of the upper Connecticut 
through the lower Ammonoosuc to join the Passumpsic waters at Woodsville (Wells river, Vermont). Between these two valleys and the field of our inquiry there happens to be a fine development of Paleozoic strata with fossils, so that it is possible to know with certainty the age of a part of the sediments. The conclusions of the early report are not all sustained by our later studies, and I have thought it best on resuming the investigation of the geology to commence with the fossils, determine their names and horizon, and follow the beds into their associations with other rocks.

\section{Fossils}

AGE AND OCCURRENCE

The fossils from Fitch hill, Littleton, New Hampshire, were submitted to Mr Charles Schuchert, of the National Museum, Washington, who reports on them as follows: "The Littleton fauna is certainly middle Upper Siluric. The species suggest the Niagara, and there is nothing so recent as Lower Helderberg." *

Owing to the delay in preparing the manuscript of this paper, $\mathrm{Mr}$ Schuchert adds a later list $\dagger$ of the collection of the Littleton fossils in the National Museum, arranged according to their occurrence in the black shale or the limestone. In addition to those sent by myself, he examined those gathered by T. Nelson Dale several years since.

Cup coral.

SPECIMENS FROM BLACK SHALE

Favosites.

Leptæna rhomboidalis (Walcott's Strophomena rhomboidalis).

Strophonella cfr. funiculata (found among Strophomena rhomboidalis).

Conchidium cfr. knighti (Pentamerus knighti of Billings).

Rhynchonella (Wilsonia?) (Walcott labeled it "allied to Trematospira multistriata").

Atrypa reticularis?

Spirifer cfr. sulcatus.

Spirifer cfr. plicatella or S. niagarensis.

Pterinea cfr. emacerata.

Calymmene tail.

Dalmanites cfr. caudatus and limulurus (Walcott named it D. limulurus).

SPECIMENS FROM LIMESTONE

Stromatopora.

Halysites catenularia Linné.

* From letter dated April 14, 1903.

t The date of this letier is May 11, 1904. 
Syringopora with slender corallites.

Favosites, at least two species.

Conchidium cfr. knighti.

Gastropod related to Polytrophis alatum Lindström.

(See Pumpelly in Amer. Jour. Sci., iii, 35, 1888, pp. 79-80.)

\section{SPECIMENS FROM LAKE MEMPHREMAGOG}

$\mathrm{Mr}$ Schuchert has also examined a collection of fossils from Owls head, lake Memphremagog, about 60 miles to the north of Littleton. No Silurian species were found among them. He reports that they represent the typical Onondaga limestone fauna of the New York Devonian.

Mr A. E. Lambert, a graduate student at Dartmouth College, has made further collections of the Littleton fossils, and has furnished a description and photographs of the Dalmanites, which are appended to this paper.

\section{THE TYPICAL FOSSILIFEROUS AREA}

The best localities are within an area 7 miles long and 2 or 3 miles wide, from the north part of Littleton to the north part of Lisbon. Limestone is not well shown beyond the south base of Manns hill, and the old Clark and Burnham quarries are on what is sometimes called Farr hill. The associated rocks cross Manns hill into Dalton. I can not present a satisfactory section at the north end of the tract because of the existence of dislocations which are not understood. On the east there is a foliated granite, a mile and a half in width, reaching nearly to the Parker observatory on the top of Palmer mountain. This summit is occupied by slates, with a general northwesterly dip of the cleavage, which are allied to those to be mentioned farther south. Some of the strata are silicious. A mile west, on the ridge between the sources of Palmer and Parker brooks, the limestone appears, 60 feet wide where quarried, and carrying Favosites and crinoidal fragments. A sandstone flanks the limestone to the west. All the dips are about vertical. It is succeeded on the west side by an argillitic schist allied to hornfels.

The sandy rock is sometimes a well defined sandstone (a quartzite) and a partial or complete aggregate of crystals of quartz developed in a slate or in pure limestone. Because of the angularities it is somewhat analogous to the buhrstone used for millstones, and has locally received that appellation. On the whole it is probable that the band represents a single horizon, while it is easy to understand its origin from a sand, slate, or limestone. Imagine these rocks permeated by water carrying silica in solution. Crystals may form either by themselves or on grains of sand for nuclei, and the result will be a rock mostly composed of 
crystals. Sections across specimens of sandstone from Fitch hill show the secondary enlargement very much like that described from Wisconsin and elsewhere.* It is also conceivable that a part of what is termed "induration" may be the result of the deposition or interpenetration of strata by amorphous silica.

There seem to be two ranges of this sandy rock, coming near together on Manns hill, in the north part of Littleton, and diverging so as to appear on both sides of the Blueberry Mountain range, where they are disposed in a synclinal attitude. They are both represented in figure 1 of plate 42. This section extends from the village cemetery in Littleton along the Waterford road, past Fitch's house. At the east end the rock is a granite overlaid by the quartzite (ss), and then by the limestone before coming to Parker brook. A few fossils have been found in the limestone on both sides of the brook. After passing diorite the sandstone is again in evidence, both outcrops dipping westerly. The granite (protogene) crops out to the west of the sandstone, and also more abundantly near Fitch's house. Crinoidal stems have been found in thin bands of limestone in a slate quite near a fork in the road, and the rock is supposed to be a continuation down the hill from the fine exposures of fossiliferous strata represented in figure 2, plate 42 .

The best fossil locality is near the residence of Mr Frank Fitch, about 2 miles west of the Littleton railroad station. The section through it, figure 2, suggests that the age of the coralline layers (1) is greater than that of the trilobite slate (2), while above them both are two other distinct bands of limestone-one quite pure calcium carbonate (3) and the other magnesian (4), neither of which contains fossils. The trilobite slate is calcareous and distinct from the argillite. The total thickness of these members must be from 200 to 300 feet. Above the limestones is a band of coarse sandstones (5), perhaps 25 feet thick. Hawes called it a "half fragmental quartz schist." As it contains both well rounded pebbles and enlarged mineral fragments, the term is not inappropriate. It is believed to be the equivalent of the sandstone, quartzite, or buhrstone previously mentioned. Still above the sandstone is a thick mass of argillite (6). On Fitch hill the amount is small, and it has been partially altered into a hornfels (novaculite) (7) because of contact with a diorite which occupies the summit of the hill and stretches on toward Kilburn's Rest for half a mile.

The section shown (figure 3) crosses Fitch hill a little to the south of figure 2. The order is the same as in figure 2, with the duplication of

* R. D. Irving and C. R. Van Hise: Secondary enlargements of mineral fragments in certain rocks. Bulletin 8, U. S. Geol. Sarvey. 


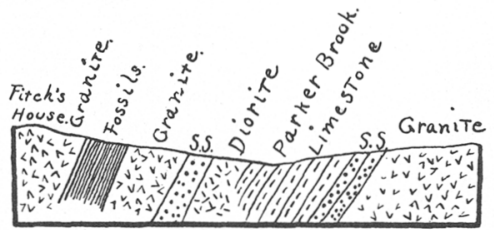

Fiq. I. Section along Waterford Road

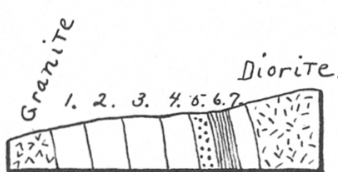

Fig. 2 Fitch Hill

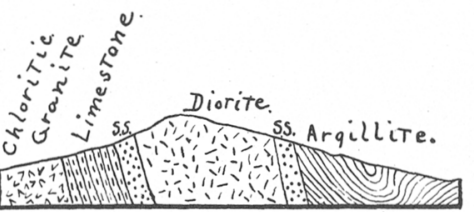

Fig. 3. Section across Fitch Hill.

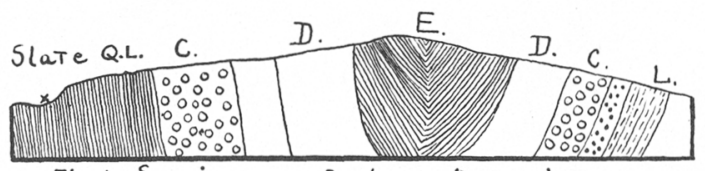

Fig.4. Section across Bluelerry Mountain.

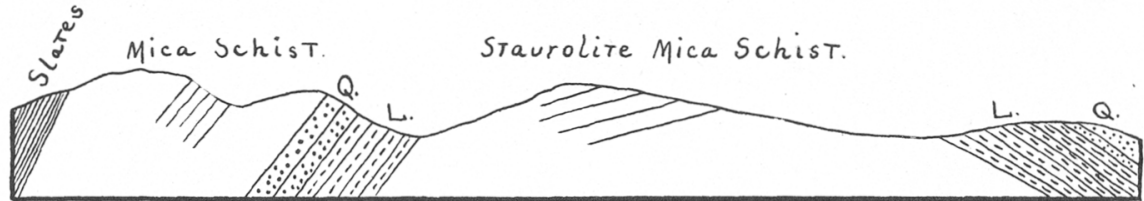

Fig. 5. Section three miles long from Sugar Hill towards NorTh Lisbon.

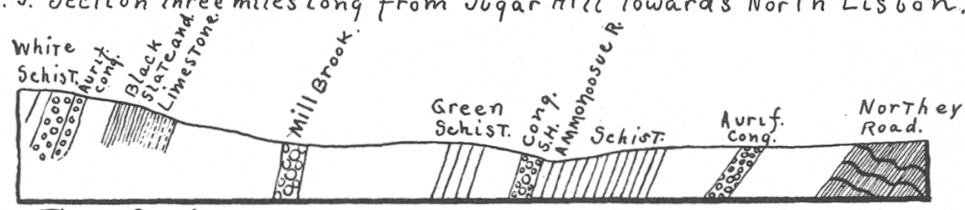

Fiq. 6. Section across Ammonoosuc Valley at Salmon Hole Brook.

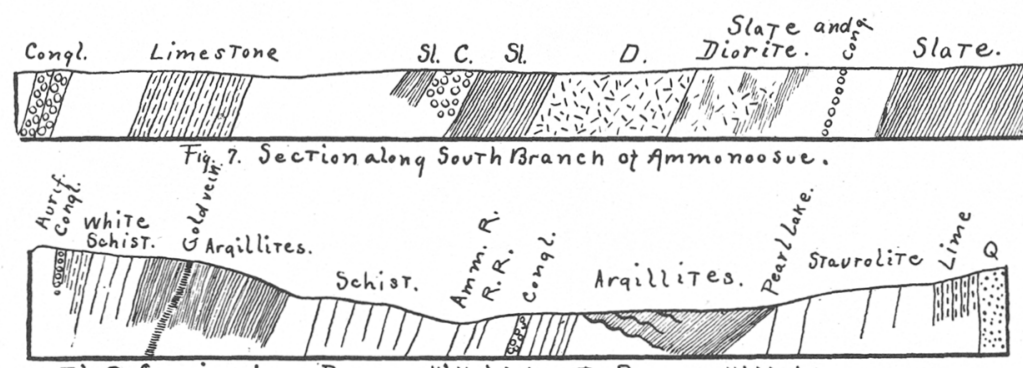

Fig 8. Section from Bronson Hill, Liston, to ParkerHill Lyman. 


$$
+
$$


the sandstone (ss) and the addition of a synclinal of slates at the eastern base of the hill.

The Blueberry Mountain range extends from Fitch hill southerly through Littleton, Lisbon, Lyman, and Bath and is a mass of argillite with a synclinal structure throughout. A typical section, figure 4, plate 42 , is that from the slate quarry across to the Ammonoosuc, about 2 miles southerly from the fossils in the Fitch pasture. It shows the fossiliferous limestones at the base on both sides $(L L)$ overlain by sandstone and conglomerate $(C C)$ and two kinds of slate, the lowermost $(D)$ being very black and the other $(E)$ drab, with a total thickness estimated to be 1,500 feet. Layers of grit alternate with some of the slates. The basal parts of the argillite carry a coarse conglomerate to be described later.

Taking the Blueberry Mountain range as a whole, it may be said to commence in Bath, has been cut deeply in Lyman by Smith brook and Mill brook, and shows a more decided gap just north of Fitch hill, having been eroded by a branch of Parker brook, which has removed nearly all the slate. Considered as a continuous elevation, the range should connect with the Dalton mountain, but deep erosions on both sides of Manns hill exhibit other rocks than slate. The topography of the northeastern part of the range is shown on the Whitefield quadrangle of the United States Geological Survey.

The fossils characterize only the basal limestones, which are middle Upper Silurian. There is certainly enough thickness of strata in the sandstone, slates, and conglomerate superposed on the limestones to suggest at least the residue of the Upper Silurian, and perhaps the Devonian. Rocks of similar petrographic character may be followed down the Connecticut valley into Massachusetts (including Bernardston), a distance of 150 miles, where Devonian fossils have been recognized. Fossils of this age adjoining lake Memphremagog have been mentioned above, 60 miles distant, but in a parallel basin. That horizon is higher than anything known in northern New Hampshire or Vermont.

\section{IGNEOUS EJECTIONS}

Omitting for the present the description of a complex series of schists adjoining the Blueberry synclinal, reference must be made to a different class of rocks. It may be truthfully said that this synclinal in Littleton rests on igneous materials. Below and in contact with the fossils on Fitch hill the rock is a chloritic foliated granite (protogene of Hawes). Above the fossils it is a coarse diorite which has converted the slate into hornfels. Along the east base of Blueberry mountain are lenses of horn- 
blende schist. Sections to the north of Fitch hill would illustrate the presence of other igneous rosks.

These eruptive rocks, being misunderstood in our early studies, caused us to announce what now seems to be very singular conclusions. Our teachers had taught us to believe in their sedimentary origin. Diorites, diabases, and protogenes were simply altered sediments, and were relegated to a different class from the truly igneous masses of the same names, with the convenient prefix of meta. Thus a metadiorite was not to be thought of as being an igneous mass, but a metamorphic schist, having the same minerals with its congener. The presence of foliated planes indicated stratification. The influence of this theory seems to have affected the opinions of Doctor Hawes, whom I employed to write up the lithology of the New Hampshire rocks. My advisers, however, disagreed as to the age of these schists, the one class referring them to the Huronian (the original "Quebec group"), and the other to the higher place indicated by the fossils. I now regard the foliated schist as truly igneous.

It should be remarked that I am not speaking of the green schists extending through the middle part of Vermont between Canada and Massachusetts, but only of the Connecticut Valley range, which widens very much in the northern part of New Hampshire; and it is an interesting circumstance that when one wishes to understand the petrography of these crystallines he must consult the descriptions of the original Huronian rocks about lake Superior. It was perfectly natural for those who were observing the similarity between the eastern and western schists to believe them to be of the same age. Possibly the tables may be turned some day, and a portion of the schists now called Algonkian may be proved to be Paleozoic.

Little need be said of an outcrop of augen-gneiss or porphyritic granite in the corners of the towns of Littleton, Bethlehem, Whitefield, and Dalton. It is the most northern area of that rock in the state, and there are no facts at present known to make clear its relation to the modern groups. It does not seem to have sent out branches into the adjacent formations.

A somewhat triangular area of granite, both massive and foliated, lies westerly from the porphyritic variety. It contains occasionally inclusions of schist in its western part. It is doubtful whether it extends easterly into Bethlehem, as represented on the state map. It is more closely allied to the chloritic granites on Parker brook than anything else.

The most extensive granitic area is that called in the report Bethlehem gneiss or protogene. A characteristic variety, identical with the " epidotic mica gneiss" from Lebanon, is number 38 of the educational series of 
rocks described in bulletin number 150 of the United States Geological Survey. It comes from another area, but both rocks are the same in composition and appearance. The epidote is common, but not universal. The Bethlehem area extends easterly into Whitefield and Jefferson, and is very commonly foliated. It narrows to a point in North Lisbon, and seems to have cut off the northeastern extension of the Paleozoic strata of the Ammonoosuc district. The foliated planes have an average dip of about 70 degrees north 30 degrees west. Were it not for abundant inclusions of mica schist, one would be inclined to retain the old name of gneiss or schist for the group. The fragments are particularly abundant in the western part of the area, which, as will be seen readily on the geological map, plate 43 , is to a certain extent coterminous with the apparent place of the schists that have been absorbed by the igneous intrusions. Portions of the mass may be the original slate thoroughly interpenetrated by an igneous paste, but it has been so changed that it more closely resembles the granite than the original strata.

\section{HoRnBlende Rocks}

These do not cover large areas, but are quite common, and of too small extent to be represented on the map. The most important is on the Ammonoosuc, above the village of Lisbon, following up the Oregon road toward the argillite. Smaller patches are common in the LisbonSwift water complex, and supposed to be of igneous origin. There are besides many crystalline schists containing hornblende or actinolite needles of secondary origin.

A sample of a dike cutting and altering the slates at North Lisbon was submitted to $\mathrm{Mr}$ W. C. Phalen, who reports as follows:

"Number 2.-This rock has a schistose structure, and there is evidence of its schistose nature even in the thin-section that has been studied. Hornblende needles in abundance, brown mica, magnetite, quartz, and feldspar constitute the major portion of the rock, which might appropriately be termed an amphibole schist."

This report is of value because, in connection with the observed phenomena, it seems to be proved that the hornblende schists of this district are of truly eruptive origin, and that the date of their ejection is posterior in time to the age of the slate. The hornblende schist seems to be allied to diorite rather than to diabase.

\section{Contact Phenomena-Lyman Schist}

Quite a large class of rocks have been affected by these igneous intrusions, which were not well understood at first, for the study of the 
famous Mount Willard locality by Doctor Hawes was not undertaken till after the close of the survey. He had described a curious rock quite near the fossils on Fitch hill under the name of novaculite, which resembles the hornstone of the "Thite Mountain notch. It is a light gray, massive, homogeneous material resembling felsite, and, like that, fusible before the blowpipe. As studied microscopically, it is found to be an excessively fine grained mix ture of much quartz, little orthoclase, minute mica films, and grains of calcite. This compact rock, which originally was slate, is so limited in amount on Fitch hill that no one can doubt its origin from contact with diorite; but there are many square miles of similar rocks in the district which would be referred to a similar origin were it possible to believe the thermal influences could have been so widely extended. In my report I gave a local name to this materialLyman schist-and several ranges of it can be described. Doctor Hawes speaks of it as identical with the novaculite, using the general name of argillitic mica schist. It is composed of fine quartz, feldspar, mica, chlorite. and various accessories. With much chlorite the color is green, and a preponderance of the micaceous ingredient gives it a soapy feel. The phyllites and mica slates belong to the same group. A careful analysis by Hawes indicated that the sample tested had the composition of an ordinary clay minus the larger part of the water, but he regarded the mass as made up of recrystallized minerals, not fragmental. Still it is a connecting link between argillite and mica schist. This does not necessarily mean that the schist was not of fragmental origin-only the primitive character has been obliterated.

I have found many cases where the original fragments are still recognizable. One is in certain parts of the distribution of the "auriferous conglomerate." The pebbles show unmistakably on the smoothed surfaces of the ledge, but when cleaved the interior has the perfectly foliated structure of argillitic matarial. Even the silica has become a silicate. Some of these rocks weather so as to show pebbles several inches long, but every pebble is of the same hornfels as the entire mass when the structure has been obliterated. All these homogeneous rocks weather extensively, so that they can be recognized at once by their light color. We called them the "white schist" when in the field.

In Littleton there is a band of these white schists adjoining on the west side the chloritic granites and slates. In Lyman it seems to merge into a very coarse conglomerate, entering the town on the east side of Partridge lake, and it is also a prominent rock on Mormon hill. The high land east of Parker hill (Lyman P. O.) shows the same rock, and it continues, partly covered by argillite, to the extreme southern end of the district at Woodsville. There is a repetition of these argillitic schists, 
accompanied by other rocks, in the south corner of Lyman and the west part of Lisbon-probably a large faulted block-raised from below.

These argillitic schists, like hornfels, seem to have been produced by a widespread thermal agent, correspondi ig to igneous masses in contact with earthy materials. Whether to say the igneous mass lay near enough the surface to produce contact phenomena or to call the process "regional metamorphism," the result is the same. Materials of originally. diverse aspects have been reduced to a homogeneous paste. Hence in mapping the distribution of this altered rock it must be borne in mind that it may represent more than one original.

\section{Distribution of the Limestones}

It will now be possible to trace out the distribution of the fossiliferous limestone series. The typical section indicates that besides limestones there are dolomitic and slaty layers, which are often ferruginous. Because of the alterations, fossils may not be widespread or aistinct very far away. The best showing is the line of outcrop on the west side of Blueberry mountain. All through Littleton and into the north eorner of Lisbon the limestone with distinct corals constantly shows itself, usually in a valley. The depression may be followed to the height of land back of Bald hill in Lisbon, where the continuity is obscured by a thick blanket of till. Another valley succeeds with the same trend toward Youngs pond, but no ledges are visible till half the ascent to the next watershed has been reached. Here in abundance are the friable shales, which continue to the top of the hill (called Knapp in the report), where several large layers of limestone appear, carrying obscure corals and fragments of small crinoids. I do not wish to assert an absolute continuity of extent from the last seen coralline ledge in the north corner of Lisbon, but the same formation with its fossils is present along the line of strike. There is here a new association. On the west side is a strong band of the auriferous conglomerate, and the course of this band has been traced with exactness into Bath. The slates accompany this conglomerate throughout, and seem to lie upon both sides of it. The harder rock makes sharp bends, and the calcareous slates conform to them. A good illustration is at what has been called the Dow ledge on Smith brook in the south part of Lyman. The conglomerate lies at the south toot of a high hill, and has been so bent as to form an acute angle. Limestone bands adjoin it, displaying satisfactorily both the planes of cleavage and of stratification, conforming to the harder strata. The slates have a larger development farther south in Bath, where both kinds of divisional planes are distinctly displayed. Many additional details might be given, but it would require the use of majs of a large scale to render the delineation effective. 
On the east side of Blueberry mountain the line of limestone outcrop can be traced, but less satisfactorily. One is represented in figure 4, plate 42. Between this point and Mill brook the rock has not been seen for a distance of 4 miles along the line of strike, in an unfavorable region for observation. At North Lisbon, away from the proper line of outcrop, it is found plentifully, as will be described later. South from Mill brook the limestone with crinoidal fragments has been observed, with the accompanying black slates and auriferous conglomerates, as indicated by figure 6 , plate 42 . These outcrops are connected with the faulted block of argillitic schist, and in the very south corner of Lyman, extending into Bath, are continuations of all these different kinds of rocks.

The limestone at North Lisbon is situated along a different line of strike. Commencing near the railroad bridge below the station, it is finely developed and extends down the Ammonoosuc river for about 2 miles. The rock is white and carries large crinoidal fragments. A dike of diorite, number 3 of Phalen's determinations (see beyond), cuts this ledge. Near the mouth of Walker brook are hornblendic layers, suggestive of a metamorphic change sometimes observed in calcareous material. The importance of this range may appear in the fact that erosion has been deeper here than along any other of the calcareous lines of outcrop. Sandstones or quartzites accompany this range.

To the east there is a still stronger calcareous band. It starts near the south branch of the Ammonoosuc, about a mile southeast of Streeter pond, and follows a northeast and southwest road past the "central" school-house of Lisbon nearly to Salmon Hole brook. It underlies an equally important band of quartzite, both dipping toward the Ammonoosuc.

This duplex calcareous and silicious range is of even greater thickness in its last known development farther east, from the old iron furnace of Franconia past Sugar Hill village into Landaff, where the limestone disappears, but the silica connects with the Coös quartzite of my report, a formation traceable through New Hampshire into Massachusetts. Limestone of considerable thickness is associated with it in Haverhill, Orford, Lyme, and Plainfield. Through Lisbon the limestone usually dips easterly beneath the quartzite, though there is a synclinal at Bronson's quarry.

Thus there are five parallel bands attended by sandstone, quartzite, or conglomerate. Three of them carry fossils, including the one affording the characteristic middle Upper Silurian forms. It is reasonable, therefore, to suppose that all of them are of approximately the same age.

Figure 5, plate 42 , is a section illustrating the positions of the two 
eastern ranges, $L$ and $Q$ representing the limestones and quartzites. I do not.know whether the staurolitic mica schist between the two limestones is of inferior age. The staurolite crystals are profusely abundant and furnish both the red and black varieties known as from Mink pond (now Pearl lake), in Lisbon. The natural continuation of metamorphic influences might enlarge the slender staurolites of the upper slate. This area in the east part of Lisbon is represented on our map. Similar rocks to the south of this district have been described as newer than the quartzite.

\section{The Conglomerates}

First of all is the one termed "auriferous." My attention was turned to it in my very first visit to this region in 1868. Being very durable, it has resisted disintegration, and its stratification marks are well preserved, so that it is a safe guide to the stratigraphy of the district. The pebbles in it are chiefly of quartz, commonly less than an inch in diameter; rarely the material is of jasper, chlorite, or hornfels, the fragments having a maximum breadth of 2 inches. In some localities the pebbles have been elongated, flattened, and distorted, and I have mentioned instances where they have been fused into a homogeneous schist. A small amount of gold has been proved to exist in it in certain favored localities, whence the name, and the thickness is usually 100 feet. The narrowest is 10 , and when it reaches 300 or 500 feet there is a suggestion of duplication by folding. Over the principal area of distribution it is always found on the hilltops, because of its greater durability.

The part which is truly characteristic and uniform commences abruptly in Lyman, southwest from Youngs pond, and may be traced into Bath about 5 miles, in 2 lines. A faulted segment of the same, repeated, extends equally far to the north, reaching to Mill brook, but it does not extend so far south by a mile.

The areal distribution of this formation illustrates the nature of the forces which have variously disturbed its original continuity. As a rule, the dip is nearly vertical; the continuous band has been broken into many segments, most of which have been curved or faulted, or both. Apparent discontinuity may sometimes be the result of a drift covering. Not only is the conglomerate itself thus disarranged, but the associated formations must be similarly affected to a considerable extent. Segments may be pushed out of line by the presence of some refractory mass on one side, and every kind of orographic movement may be looked for. The result of the disturbances is the existence of a gigantic breccia, or mosaic, whose pieces may not be firmly cemented together. Curved strata will prevail until the strength of the rock gives way, and in many 
cases the crevasses have been conspicuously filled by veins of white quartz. It is as easy to determine the original line in the formation as to recognize the outline of a chimney that has fallen down.*

The language descriptive of the fragmental condition of the crust of the earth in the Ammonoosuc district is also applicable to the crystalline and Triassic areas of the southwest part of Connecticut, $\dagger$ according to Professor W. H. Hobbs. He finds the fractures correspond to several systems of joints. The two regions may be said to correspond in respect to the origin of the mosaic structure, but the displacements have been greater apparently in the more northern district.

\section{Other Conglomerates}

Secondly, there are other conglomerates of a very puzzling character. The abrupt termination of the auriferous conglomerate at its northern end south of Youngs pond has been mentioned. Its place is taken, nearly along the line of strike, by a coarse mass almost suggestive of till because of the miscellaneous arrangement and size of the fragments of green and white schist, some attaining 2 feet in length. It may be followed for 3 miles to the edge of Littleton, passing to the west of Mormon hill, which is also full of conglomerates. Slate, conglomerate, and argillitic schist are so intermingled that often any one of the three might be considered as a lens imbedded in the mass of either of the two others. These conglomerates dip southeasterly toward Blueberry mountain, at whose base is another mass of rounded fragments called familiarly by us the "egg conglomerate," some pieces attaining the size of an emu's egg. The two may possibly run into each other.

Still another conglomeratic group follows the course of the A mmonoosuc river between the villages of Lisbon and North Lisbon for 5 miles. The first one underlies the bridge at North Lisbon. The pebbles in it are white and blue quartz, hydromica schist, two or three gneisses, slates, calcareous bits, with an argillo-micaceous paste. The source of the handsome grains of blue quartz is unknown. Some pebbles are a foot long, some have been bent, flattened, and distorted. The dip is 65-70 degrees north 22 degrees west. A similar rock with friable cement crops out opposite the mouth of Walker brook on the east side of the river adjacent to a hornblendic mass. It is more strongly developed on the west side of the hornblende at the W. K. Chase house of the county map (or G. Conrad of D. H. Hurd and Co.'s atlas), and is continuous to the school-house at the bridge over the Ammonoosuc near the railroad. In front of W. Bishop's house the pebbles have been very hand-

* For a good map of these disturbances see Geology of New Hampshire, vol. 2, p. 296. $\dagger$ Bull. Geol. Soc. Am., vol. 13, and also the present volume. 
somely pressed out of shape. An exposure at $J$. Hastings, in Bath, may belong to this series, situated near the middle Upper Silurian rocks and dipping to the north west.

Figure 6, plate 42, represents a section from the Northey road on Salmon brook across the Ammonoosuc and up Mill brook on which three important conglomerates are indicated, the first the probable equivalent of the "calico rock," the second at the school-house by the bridge, and the third another mass near a trout-hatching establishment, where a new road passes down the west side of the river. Just north of the village of Lisbon and at the bridge over the river in the village, as well as farther north, are other outcrops of these conglomerates.

The last important conglomerate is represented on our section, figure 7, plate 42, 1,100 feet east of the North Lisbon bridge, and has been identified across the valley of the south branch. It contains, besides the materials mentioned beneath the bridge, pieces of soft mica schist. From fancied resemblances it received the field name of "calico conglomerate."

At first it appeared reasonable to correlate the auriferous conglomerate with related material upon Salmon Hole brook, the Landaff gold mine, and farther south. Further reflection suggests that this line of outcrops on the east side of the Ammonoosuc should be considered as the continuation of the calico conglomerate of the south branch. The Landaff rock is more like the auriferous than the other conglomerate, but we can not insist upon close correlations of coarse sediments from superficial resemblances. An apparent stratigraphic line must have a stronger determinative influence than a uniform texture.

The end of this line of conglomerate is only 2 or 3 miles distant from a range of quartzite which is often composed of coarse constituents, and the two are made to look toward each other by the occurrence of a related rock in the valley of Mill brook, Landaff, to be specially mentioned later. The eastern range is the Coös quartzite of the published report, now traceable from Sugar hill (figure 5, plate 42) southerly through the state. To correlate these two silicious formations it is not necessary to find a surface connection, since a continuation could be effected by means of a fold-probably a synclinal-beneath the eastern area of argillite terminating at Pond hill in Landaff.

It was stated that the "egg conglomerate" occupies a place near the base of the Blueberry Mountain synclinal of argillite. The "calico" rock is near the border of the eastern argillite range, soon to be mentioned. While it is difficult to adjust the dips, the geographic positions suggest a correlation which will include the majority of all the conglomerates; they may belong to the same horizon near the base of the argillite. This suggestion may be confirmed by the presence of pebbles or inclu- 
sions of slate. I have noted this fact specifically in the auriferous conglomerate on Smith brook in Lyman, in the conglomerate near Mormon hill, and remarkably large pieces in the Coös conglomerate in the north edge of Landaff (Baptist church). The schist inclusions at North Lisbon may have come from slates. All the conglomerates, except those farthest east, abound in fragments of the white Lyman schist. The green Lisbon schists occur sparingly.

It seems proved, therefore, that all these conglomerates are closely related to one another. Stratigraphically they overlie the fossiliferous limestone of the middle Upper Silurian, and also the sandstone of Fitch hill, from which last they are separated by a few feet of argillite.

\section{A reas of Argillite}

Enough has been said of the Blueberry Mountain main range of argillite-a possible Siluro-Devonian basin, extending from Bath to Littleton, 20 miles. It is traversed by veins of auriferous quartz. At an artificial tunnel in Lyman this rock has been pierced for nearly 700 feet, and gives as much evidence of disturbance by folding and faulting as the auriferous conglomerate. I can not find marks of strata distinct from those of cleavage. At two localities there is a resemblance to ribbons of color produced by a minute bending and faulting. At Kilburns rest in Littleton the slates have been shattered as if by a crusher, and the fragments reunited by some sort of adhesion. Other ledges have been faulted slightly since the ice age. Crystals of staurolite are wanting in this area, though small garnets are sometimes seen. In my report I made the presence of staurolite indicative of a difference in age. It seems to be generally believed that this is not a necessary distinction, because the secondary minerals may be developed by metamorphism. If so, the next argillitic area to be mentioned, on the east side of the Ammonoosuc, must be regarded as a repetition of the first. It is 7 or 8 miles in length, less mountainous, cut deeply by the south branch, terminated at the north end by the great eruption of Bethlehem granite, and, after continuing through Lisbon, ending in Landaff like a synclinal. It was called Coös slate in the report. It is easy to find at several localities clear evidence of banded strata crossing the cleavage planes at right angles. While the cleavage planes dip generally from 60 to 70 degrees to the north of west, the strata at the western edge of the argillite dip from 25 to 30 degrees southeasterly. One locality is along the gulf road from Lisbon to Breezy hill, and another at the crossing of Salmon Hole brook, by the carriage road, a mile east of the Sugar Hill railroad station (see plate 42, figure 6). Slender staurolites are found in it west of Pearl lake, and especially at a bend in the south branch, 3,000 feet east of 
North Lisbon. Multitudes of small garnets accompany the staurolites, and in several ledges the garnets exceed 1 inch in diameter, accompanied with large patches of masonite or chloritoid. There are very few outcrops of the slate north of the line of the south branch, so that the details of this section, as shown in plate 42 , figure 7 , are important, illustrating the presence of erupted dikes and their effect upon the sediments.

Under the bridge at North Lisbon lies the conglomerate already described. For 600 or 800 feet to the east along the river no ledges are visible, but the thick, white, fossiliferous limestone a few rods to the south must represent the rock in place. On the north side there is an outcrop of argillite supposed to lie east of the limestone along the line of strike, and it is the first rock seen on the river's bank, 1,100 feet from the bridge, with a dip of 45 degrees north, 32 degrees west. I think it partly calcareous. Next is the calico conglomerate, 80 feet thick, having a dip like that of the slate. To the east the slates appear again, with higher dips, and disturbances produced by dikes of diorite (number 2 of Phalen), which has silicified the sediments by contact, changing it into a quartzite. These altered strata are about 55 feet wide, including the diorite. Following these are in order 50 feet of slate not much altered; a diorite dike 30 feet wide (number 4 of Phalen) filled with nodules very similar to the elliptic bunches described by J. Morgan Clements in the Vermilion iron-bearing district of Minnesota * and by him correlated with the pseudo-bombs of the Aa lava of Hawaii.

The thickness of the slates seen along the bank to this point amount to 146 feet. Next succeeds another diorite 304 feet wide. After that no rock is visible for 50 feet, and then there are 165 feet of silicified slates, followed by another Aa diorite 20 feet wide. Then follow in order 30 feet of slate, 85 feet of diorite, 20 feet of indurated conglomerate, accompanied by hornfels with altered slates for 320 feet. Beyond this point the slates are more nearly normal up to 2,600 feet from the bridge. The ledges become steep cliffs for an eighth of a mile farther, and there is an elbow in the course of the stream, where is the locality of the large garnets and chloritoids.

These details were obtained in 1903 . The locality was visited earlier by Doctor Hawes, who was especially interested in the diorite or amphibolite, number 215 of the New Hampshire special collection. Other specimens obtained from this section are numbers 152, 231, 232, 234, 235 , and 245. That the diorite is not an altered sediment is proved by its actual presence in dikes, its Aa structure, and by the production of contact phenomena. Why Doctor Hawes and myself should have both failed to recognize the igneous nature of the diorites is singular, but our 
minds were preoccupied with different theories for their origin. $\mathrm{W}^{\top} \mathrm{e}$ had accepted the view of the presence of older crystallines, and the phenomena seen along the stream were explicable on that theory. These diorites are more abundant to the north of the section near Streeter pond, but have not been seen farther south because of an extensive covering of the rocks by drift.*

\section{LISBon-SwiftWater CoMpleX}

In the state report the local name "Lisbon" was applied to the green schists, and "Swiftwater" to an indefinite group of mica schists, slates, and conglomerates, both making parts of one whole. For convenience in description the double name may be employed, it being understood that the fossils found in the limestone will give character to the whole, though they have not yet been seen in the southern portion of the area.

More particularly the Lisbon rocks are green chloritic schists and sandstones, igneous diorites, granites, and protogenes, at first thought to be stratified; hydromica schists, quartzites, limestones, conglomerates, etc. The Swiftwater rocks are mica schists, quartzites, hornblende schists, slates, argillitic and sericite schists, and obscure conglomerates. These two groups were separated from each other on the published map, but further explorations indicate that none of these rocks are restricted to any particular horizon. The last named series seems to underlie the other. At the northern end of the district the Coös group was distinguished from the other, but our later studies would indicate that these quartzites and mica schists, with others of an argillitic character at this locality, belong to the same general Paleozoic Lisbon-Swiftwater complex. The greater breadth of the southern part of the complex may be due to duplication by folding.

The quartzites of Littleton seem to be silicified mica schists and merge into the strata connected with the limestones on Manns hill. The formation of the broad valley in which the village of Littleton is situated has removed or concealed the ledges by alluvial deposits, but their continuation to the south is evident on Walker hill, in Lisbon. A characteristic whetstone mica schist is traceable from South Littleton across to the well known quarry in the north part of Lisbon. All these rocks underlie the coralline limestone.

\footnotetext{
* Three varieties of the rocks from this section were sent to Professor G. P. Merrill for deter. mination, who turned them over to Mr W. C. Phalen, who sends the following descriptions :

Number 2 al ready quoted, page 467.

"Number 3 is practically the same as number 2, so far as constituents go. There is a good development of plagioclase, and for that reason the rock might be classed as diorite." (Mentioned on page 470 .)

"Number 4, principally fine grained aggregate of amphibole and feldspar, and may appropriately be called Lamprophyre if in dike form or a diorite if in massive form."
} 
In passing from North Lisbon in a northerly direction over the hills, the granite (Bethlehem) reaches nearly to the top of what may be called the north Walker hill, and it has evidently increased the tilt of the strata by its protrusion, and has silicified the adjacent schists. Sericite schists and a sprinkling of hornblende crystals in other strata come next, followed by a chloritic conglomerate with flattened pebbles, which may be located at the intersection of the town line by a carriage road. To the west is a considerable mass of diorite before reaching extensive argillites forming the eastern flank of the Blueberry range.

Going west from North Lisbon, the limestones are overlain by sandstones, the conglomerate under the bridge, drab quartzites and mica schists carrying scant calcareous strata, all dipping about 50 degrees northwesterly. Then for half a mile no ledges are exposed, because of the presence of the south Walker Hill morainic mass. Then may be seen slaty rocks, including the well known whetstones, a fourth of a mile wide, with a smaller inclination. The last mile of this section to the Blueberry slate range is mostly taken by green chloritic schists and an igneous mass of hornblende.

The next section, up the Whipple brook on the "Oregon road," discloses only hornblende rock, with some limestone at the start, most of the rock being covered by the quaternary floodplain. It is presumed that some of this hornblende schist may have been altered from limestone, and thus not have been originally an igneous rock.

The next traverse across the complex lies along the courses of Salmon hole and Mill brooks, as portrayed in plate 42, figure 6. Above or to the west of the calico conglomerate are dark micaceous quartzites, with iron ore nodules and black argillites dipping 45 degrees north west. The conglomerate by a school-house at the Ammonoosuc crossing is close at hand; and not very far to the south, but not on the section line, is a white silicious rock carrying many minute curvatures suggestive of a possible different interpretation of the dip. West from the schoolhouse are green quartzites. chlorite phyllites,* and hornblendic layers. The coarse conglomerate near the mouth of Mill brook is interstratified with thin layers of hard green schists, and there is a notable development of this green rock before reaching the blank and drab argillites.

The next traverse line is indicated in plate 42 , figure 8 , a general section from the Bronson limestone quarry in the east part of lishon, through the village to Parker hill, and about 3 miles south of the section represented in figure 5. Only one of the bands of limestone and quartzite is visible, and its position and relations to the staurolite mica sthists are quite different. A faulted block is suggested both by the vertical

* No. 127 of the Educational Series, U. S. Geol. Survey. 
attitude and the highly mineralized character. The argillite is identical with that at the west end of the section shown by figure 5 . The LisbonSwiftwater complex properly begins to the left of the argillite. For a distance of 140 rods it is a mass of quartzites, obscure sandstones, and sericite schists with a northwesterly dip of 50 degrees. There is a slate in the edge of the village past a conglomerate, formerly regarded as the west border of the Swiftwater series. The strata east of this slate have been estimated to aggregate 4,000 feet, those to the west 3,500 feet in thickness. At the crossing of the Ammonoosuc may be recognized a coarse conglomerate variously modified and alternating with hard green schists. To the west are both hard and soft chloritic bands, sericite schists, chlorite-phyllites, and impregnations of galena and chalcopyrite. Near the west border is a large vein of white quartz outcropping conspicuously for 2 miles north and south, and thus enabling us to believe in a distinct unconformity of the schists beneath the argillites.* The slate belt is the Blueberry range and has the distinction of holding auriferous quartz veins which are now being worked by a company. West of the slates is a strong characteristic development of the argillitic schists, followed by dolomitic slates and auriferous conglomerates.

A section along Mill brook, in Landaff, should start with the Coös quartzite, which has quite a low northwesterly dip-say 15 degrees. It does not crop out on the stream, but on the high land, both to the north and south. The first rock visible down the stream is much like hornfels with hornblende. Half way to the Ammonoosuc river is a very coarse conglomerate by an old sawmill, dipping 75 degrees north 60 degrees west. It shows more evidences of heat than either of the quartzose ranges. Below this are an obscure schistose conglomerate and various greenish schists. At the Ammonoosuc are sericite schists; all these exposures with northwesterly dips. There are small areas of granite on Green mountain and Pond hill.

The section along the wild Ammonoosuc is the most typical, passing through the village of Swiftwater. The dips at the east end are higher, being as much as 60 and 70 degrees northwesterly and only 40 degrees on the lower side, suggesting an anticlinal or faulted segments. The first are micaceous, friable, ferruginous quartzites, with intercalated thin glossy black micaceous bands. Next are hornblendic strata and mica schists containing crystals of chlorite. Below the village are mica schists, sericitic, feldspathic, and at length a strong development of slate, followed by a coarse conglomerate midway between the village and the Ammonoosuc. The balance of the distance across to the argillites of the Blueberry range, about 2 miles, is occupied by green schists. 


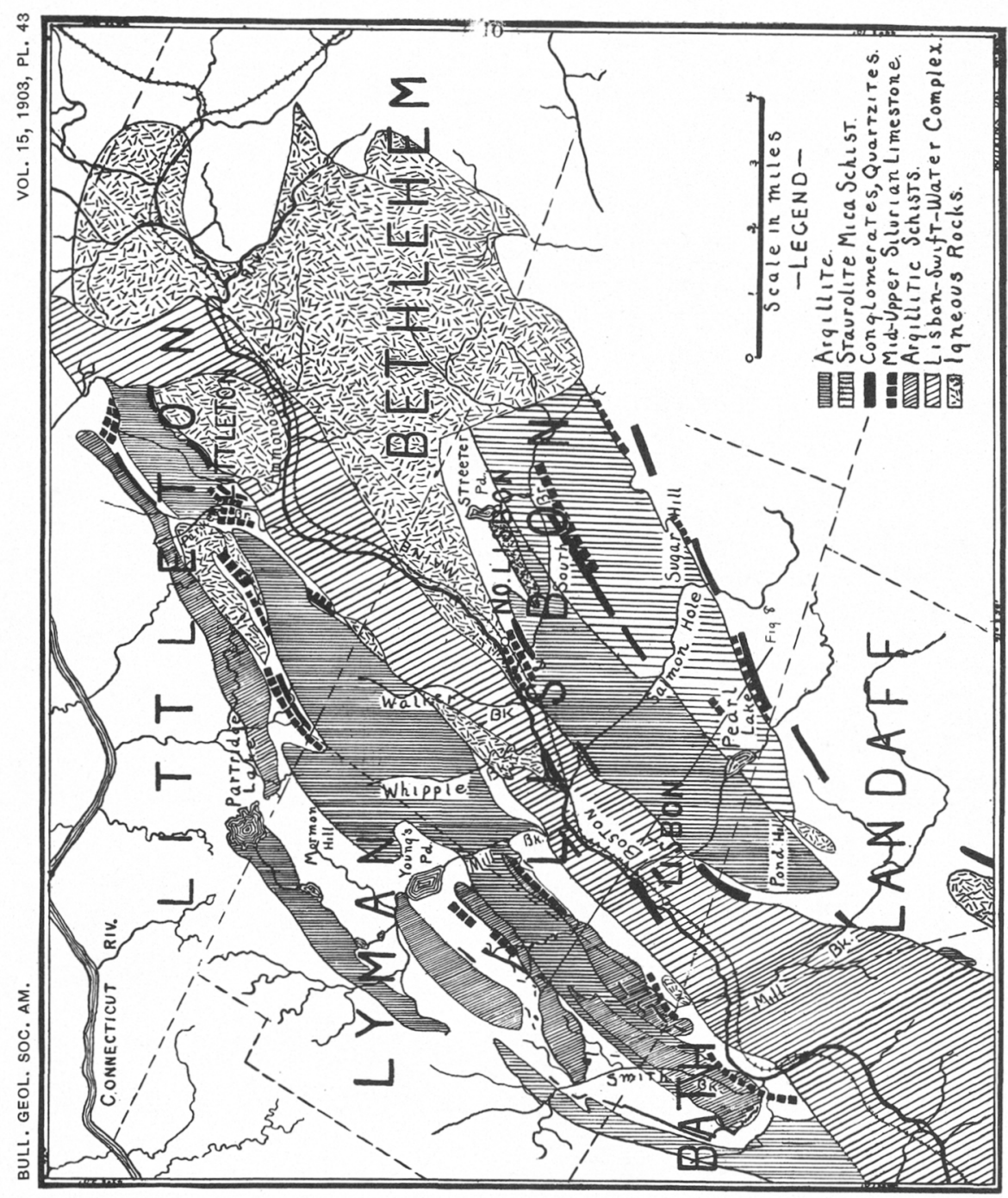


Plate 4 is drawn to represent the regions specially described in this paper. Owing to the small scale, many of the names mentioned, the roads, and other details are not given. The order of the formations given in the legend, with the exception of the igneous rocks, is from below upward. The Lisbon-Swiftwater complex extends centrally through the area, occupring the ralley of the Ammonoosuc rirer. In earlier maps the area in the eastern part of Littleton and a narrow strip adjacent $t$, the granite through the township was referred to the staurolite mica schist group, of which there still seem to be a few relics, and much more has apparently been absorbed by the Bethlehem granite (paye 46:5). The llank space in Iyman and Iittleton is mostly occupied ly the Lisbon rucks, and the west line of Lyman coincides with the Gardner range, areraging 2,000 feet of altitude. In the north part of Bethlehem the vacant space eating into the granite represents till. Farther south the granite itself might have been represented. The blank space to the southeast of the schists in Lisbon and Landa ff is chiefly gneiss. There is also a large vacant space indicating till near Streeter pond. The scale proves inadequate to show satisfactorily the distribution of the auriferous conglomerates in Bath and Lyman; nor is the coarse conglomerate which merges into the argillitic schists to the north on Youngs pond and west of Mormon hill represented. Only one section, the most general one (figure 8 , plate 4\%), is indicated. To have inserted the others would have obscured important details.

\section{Coxchtsioss}

This paper may be regarded as a report of progress. The relations of the several formations are better understond than ever before, but much remains to be elucidated. It is desirable to place on record what seems to be established, to serve as a guide for later studies.

1. It is clearly established that there is a horizon of middle Upper Silurian age in the limestones of the Blueberry Mountain area.

2. In a direct upward stratigraphical succession above the limestone there are a sandstone, an argillite, coarse conglomerate, dark and drab slates. There are no fossils to decide whether any of these strata are newer than Upper Silurian, but the raried succession and the considerable thickness suggest the presence of some Devonian.

3. There is equal uncertainty as to the exact place of the supposed inferior schistose complex and the argillitic schists. At present the general term of Lower Silurian (Ordovician) may be applicable.

4. A long list of what were formerly called metamorphic schists may now be classed as eruptive igneous rocks. such as the porphyritic gran- 
ite, Bethlehem granite, Lake gneiss, diorites, and protogenes, to say nothing of what has always been recognized as granite and diabase. The periods of their extrusion were evidently middle or late Paleozoic.

5. It is a fine field for the study of the metamorphism of sediments and the foliation of eruptives. There are illustrations of contact phenomena, the formation of hornfels and argillitic schists, a secondary enlargement of minerals, the modification of the forms of pebbles, the development of large garnet and staurolite, and the obliteration of the planes of stratification.

6. The general results of our studies tend to restrict the areas of the more ancient rocks, and to increase those representing the Paleozoic groups in the adjoining regions of northern New Eugland.

\section{Deschiption of Dalmanithe lunatus; by Avery E. Lambert}

The only fossil bearing locality that has. as yet. been reported in the state of New Hampshire is in the town of littleton, about 2 miles to the west and north of the village.

The fossiliferous character of this area was discovered by Professor C. H. Hitchcock in $18 \overline{7}$, while, as state geologist, he was engaged in studying the region.

The fossils, mainly coralline in character, were sent to MIr Billings, a Canadian geologist, for identification. Mr Billings believed, from the evidence which they presented, that the general term "Helderberg" could be applied to indicate the geologic horizon of this area, but later observations seem to justify the conclusion reached by $\mathrm{W}$ alcott that it belongs to the Niagara.

The first mention of trilobites occurring in this region is to be found in a report by T. Nelson Dale.* The material found by Mr Dale was examined by C. D. Walcott, who identified the trilobite with Dalmanites limulumes. $\dagger$

The locality in which the trilobite occurs is on the northern slope of a range of hills known as the Blueberry mountains. This particular section of the range is owned by Mr Frank Fitch, its local designation being "Fitch hill." The fossil bearing rocks are distant from the road some 400 or 500 feet.

In ascending the hill from the road which passes in front of $\mathrm{Mr}$ Fitch's residence one crosses first a stratum of igneous rock. Superimposed on it is a layer of limestone, ranging from 30 to 40 feet in thickness, in which numerous coralline fragments abound. Lying on this is the calciferous slate, in which the trilobites occur. This layer is from 6 to 10 feet thick and gradually merges into the underlying limestone.

* Proc. Cansdian Institute, Toronto, vol, sxii, no. 146, p. 69.

† Am. Jour. Sci., series iii, vol. 35, 1888, pp. 70-80. 
Above the slate, in order, is a non-fossiliferous limestone, a layer of coarse sandstone, and another, but non-fossil-bearing (?), slate.

All of the rocks of this area have been disturbed by the uplifting and tilting of the strata. This has affected the condition in which the fossils are found, many of them being badly distorted.

In the spring of $1903 \mathrm{I}$ spent considerable time in this locality, collecting material for the museum at Dartmouth college. In this material there were several excellent pygidia of the trilobite and two cephalic shields, one of which was practically free from distortion. The present report is based on my study of the material which I obtained at that time.

There are good reasons why the trilobite from the Littleton area should not be considered identical with $D$. limulurus, as determined by Walcott. In the first place, the greater breadth of the cephalic shield in relation to its length gives it a very marked crescentic, or lunate, appearance. The length of the head from the cervical ring to the outer edge of the marginal limb, in what appears to be the most normal specimen, is hardly one-third of the total width. Mr Schuchert has also called attention to the absence of head denticulations.

In fact, in both form and general characteristics, the head of this trilobite resembles very closely that of $D$. pleuropteryx as described and figured by Hall.*

So far as. I am able to discover, no determinable fragments of the thorax have been found. However, many fairly preserved pygidia have been collected. The pygidium is remarkable for its great breadth anteriorly, in which character it differs considerably from $D$. limulurus, and may, on the other hand, be favorably compared to the English $D$. caudatus. $\dagger$ This likeness also extends to the character of the pygidial spine, which is short and acutely triangular in both $D$. caudatus and in the Littleton species. In general appearance these pygidia bear the closest resemblance to the pygidium of a specimen of D. pleuropteryx, named by Green from the Lower Helderberg of Schoharie, New York, the difference being not in form, but in the fewer segments in the Littleton species, in both the middle and lateral lobes.

The differences between this form and $D$. limulurus are sufficient to warrant its being regarded as a new species. In fact, in the general character of both cephalic shield and pygidium, it approaches much nearer to D. pleurnpteryx than to the Niagaran form, and I venture to suggest that it be known as Dalmanites lunatus in view of the strongly crescentic, or lunate, character of the head.

* Nat. Hist. of New York, pt. vi, vol. 3.

$\dagger$ Green, in his monograph on the Trilobites of North America (1832), calls attention to the similarity between pleuropteryx and caudatus. 
The following is a description of this species :

Dalmanites lunatus (Lambert).

Cephalon strongly lunate; length one-third of width.

Glabella consists of a large transversely oval frontal lobe, the longitudinal dimension being one-half of the transverse. This lobe is separated from the first of the three following lobes by a furrow which runs backward obliquely toward the median line. This furrow is broadest in its outer part. The length of the remaining lobes equals that of the frontal lobe. They are separated by narrow transverse furrows.

Facial furrow bounding the glabella laterally, deep and conspicuous, communicating more or less freely with the longitudinal furrows of the glabella.

Neck furrow deep and conspicuous, passing outward from the posterior termination of the facial furrow, and ending near the base of the genal spine.

Facial suture passes from before the frontal lobe of the glabella back to the posterior margin of the eye, then outward, meeting the lateral margin of the head at a point somewhat above the level of the middle of the eye.

Eyes compound, large and conspicuous, considerably elevated.

Pygidium triangular, broad, convex anteriorly, the middle lobe consisting of from thirteen to fifteen annulations, wide anteriorly, decreasing to one-half its width posteriorly ; lateral lobes eight strongly reflexed segments which pass laterally into a broad marginal limb. The segments are marked by conspicuous furrows which are near and parallel with the lower margin. The marginal limb is produced posteriorly into a short, acutely triangular, pygidial spine.

\section{Explanation of Plate 44}

FiguRe 1.-Dalmanites lunatus. Littleton, N. H.

Cephalic shield. The specimen is considerably distorted by the lateral compression of the rock. Specimen in the museum of Dartmouth College.

Figure 2.-Dalmanites lunatus.

Cephalic shield. Showing the strong, crescentic curve of the frontal portion of a normal cephalon. Specimen in the possession of the writer.

Figure 3.-Dalmanites lunatus.

Pygidium. Specimen number D. 60. C. C. National Museum.

Figure 4.-Dalmanites caudatus. Dudley, England.

The Littleton species approaches somewhat near to this species in the anterior breadth of the pygidium and the acutely triangular character of the pygidial spine. Specimen number 18,475. National Museum.

Figure 5.-Dalmanites lunatus.

Hypostoma. Specimen number D. 60. Q. Q. National Museum. 

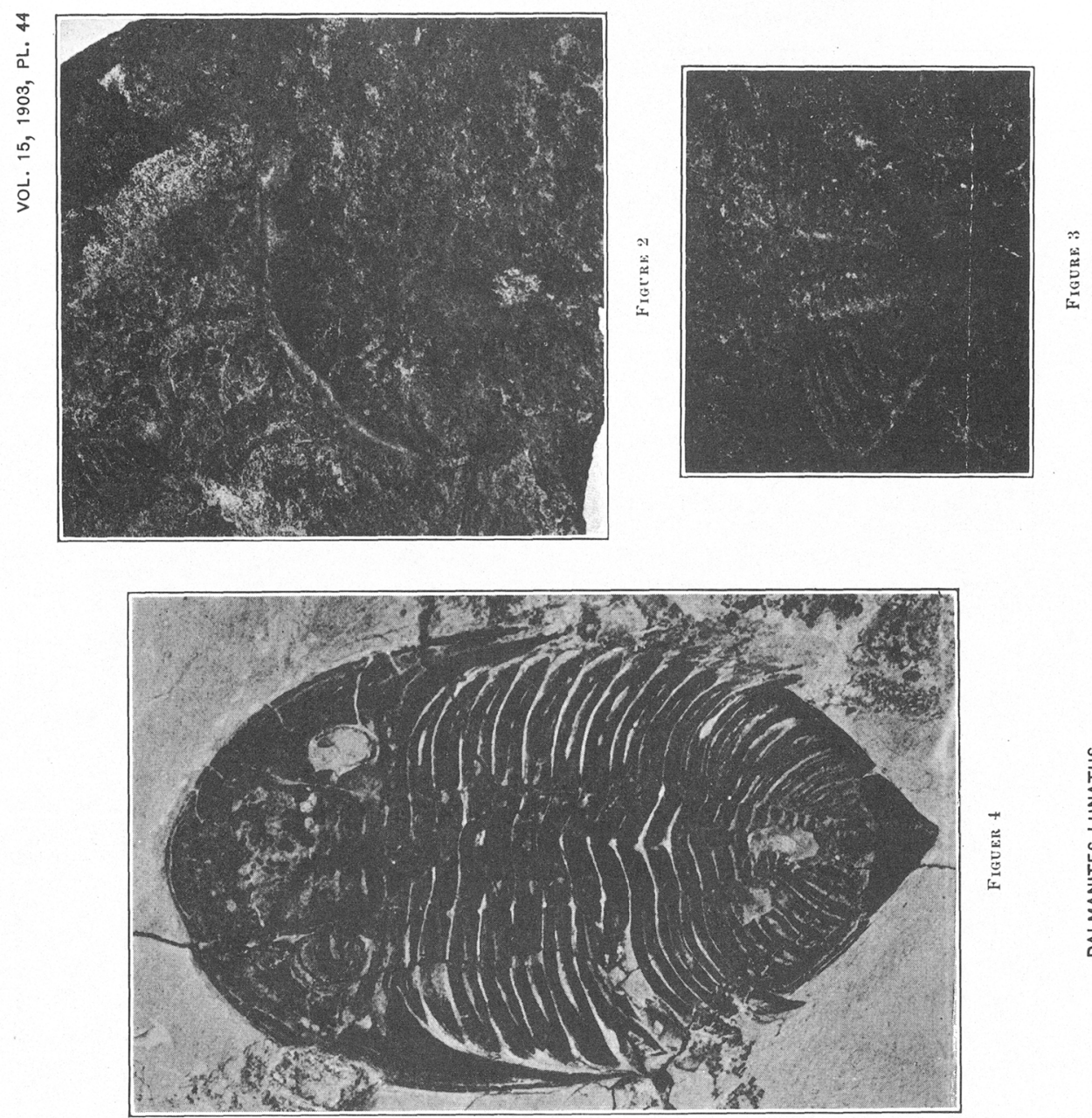

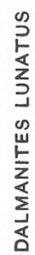
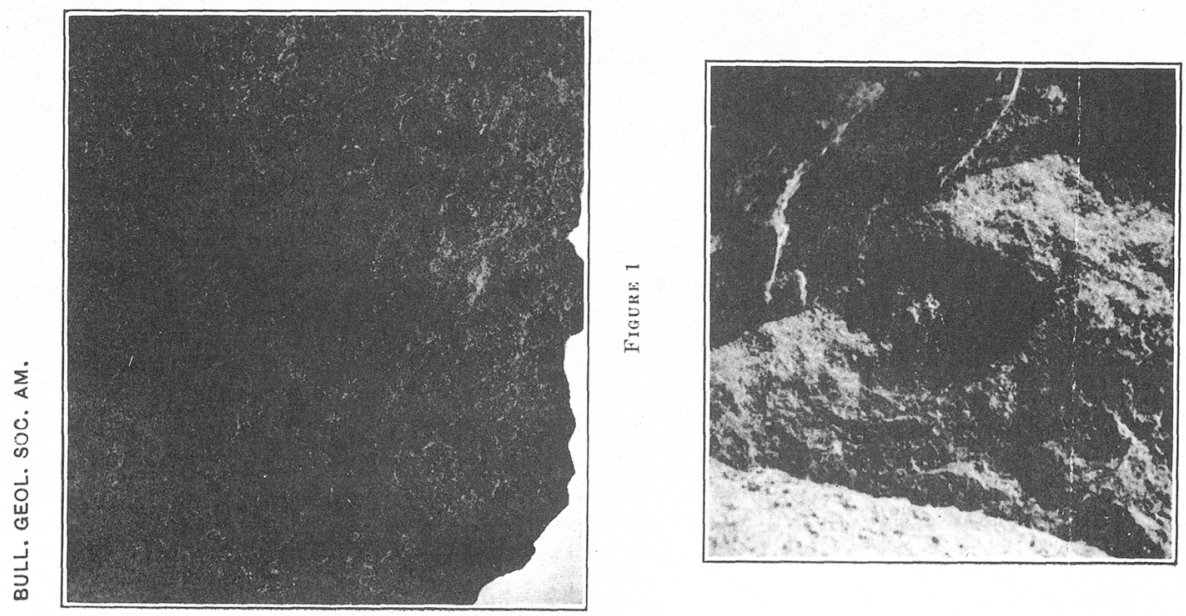

量 